\title{
CoCom trims embargo list but tightens controls
}

\section{Paris \& Munich}

Representatives from the United States, Western Europe and Japan agreed on 28 January to shorten the list of items that may not be exported to the Soviet bloc, but to tighten controls on sensitive items, according to the motto "higher fences for fewer items".

The meeting of the Coordinating Committee for East-West Trade Policy (CoCom), an organization set up by NATO governments and Japan to monitor and limit East-West trade in goods and technology with potentially sensitive applications, took on a greater significance than usual because it reflects the current thaw in East - West relations. The meeting, at Versailles outside Paris, was nonetheless swaddled in secrecy and delegates from the 16 member states left without briefing the press.

The United States deputy secretary of state, John Whitehead, came to Paris to call for increased coordination between CoCom members in respecting existing restrictions and in sanctioning offenders.

\section{Klaus Fuchs dies}

\section{London}

DR Klaus Fuchs, the nuclear physicist whose trial in 1950 for passing nuclear secrets to the Soviet Union became a turning point of the cold war, died last week in East Germany. Western comments on his death focused, inevitably, on his trial and nine years' imprisonment; the Soviet media did not mention it. The East German Party daily, Neues Deutschland, however, described it as a "political trial in connection with [Fuchs'] stance on the US monopoly of the nuclear bomb," and explained Fuchs' motive as "his steadfast opposition to the misuse of nuclear research findings for the implementation of imperialist power and intimidation politics".

Allowing for the difference in political vocabulary ("deterrence" on one side of the curtain may well appear "intimidation" on the other), this assessment is in fair agreement with those reached by the two Western biographies of Fuchs which have appeared in the past year (see Nature 327 , $377 ; 1987$, and 329,$774 ; 1987$ ).

To Neues Deutschland, however, Fuchs' trial and sentence were merely one episode in his long life as "Communist, researcher and peace campaigner", putting its main emphasis on Fuchs' services to East Germany in the last 28 years of his life, as research physicist, initiator of East Germany's nuclear energy programme, and as a member of the Central Committee of the party.

Vera Rich
But European members, notably West Germany, have made no secret of their exasperation at the sheer number of items proscribed - thought to be as many as 300,000 .

The computer and telecommunications industries in particular expect to increase their dealings with the East. Restrictions on computer memory size and speed were particularly troublesome.

One industry source complained that the CoCom rules were supposed only to hinder the export of "tomorrow's technology", not "yesterday's".

Eduard Shevardnadze, the Soviet foreign minister, is reported to echo this feeling, saying that the "cursed list" of secret technologies has already slowed development of benign domestic industries in the Soviet Union.

The US Congress is still smarting at the costly consequences of last year's breach of CoCom regulations by a Japanese and a Norwegian company. The Toshiba Machine Corporation and Konsberg Vaapenfabrikk were found to have supplied machinery to the Soviet Union allowing the development of silent submarine motors. NATO governments have had to revise detection devices to counter this progress in Soviet knowhow.

But some in Congress are suspicious of the Pentagon's timing in releasing information about the Toshiba Machine case. They feel the Defense Department was trying to head off a pending congressional move to limit export restrictions. The current meeting may serve the purpose of restoring confidence in CoCom for members of Congress anxious for stricter controls, but at the same time heading off further liberalizing of laws covering export restrictions.

The threat of a deterioration in technology exchanges with the United States, if the Pentagon's anxieties were not soothed, has made European CoCom governments keen to show willing. It is therefore thought to be no coincidence that the French secret service chose the first day of the meeting to release details of the prosecution of six "techno-bandits" accused of selling sensitive electronic components to the Soviet Union.

An illegal supply network, involving a French company, Universal Testing Equipment, was uncovered by the French secret service in October 1987, but was kept low-key. Universal Testing Equipment allegedly provided a KGB attache in Paris with a catalogue of the West German company, Rohde and Schwartz, and subsequently supplied items from the catalogue to Moscow, using false shipping documents.

\section{Soviets to launch German experiments}

Munich

THE Soviet space programme received another boost last week with an agreement between the West German space hardware company Kayser Threde and the Soviet Union for three future launches of space experiments. The agreement reflects the dramatic improvement in the reputation of the Soviet programme coupled with the problems still plaguing the US shuttle programme.

Kayser Threde, which makes hardware for the West German Aerospace Research Establishment (DFVLR), has arranged to launch three payloads of $100-150 \mathrm{~kg}$ each on Soviet Cosmos rockets beginning in 1989. The rockets will carry both life science and materials science experiments that must be done under microgravity. The specific experiments have yet to be determined.

Kayser Threde had launched 25 experiments on the US shuttle, including some laser experiments on the West German D1 Spacelab mission. But its customers became impatient with the delay (which has just reached its two-year mark) in the shuttle programme resulting from the Challenger explosion. Kayser Threde's Reiner Klett said the delay was "bad for the customers and bad for our business".

Kayser Threde talked with both the People's Republic of China and the Soviet Union before deciding to sign up for Cosmos.

Negotiations had begun over a year ago and the agreement was actually reached in December, but it has come to the attention of the West only within the past week. The Soviets' price, Klett said, was competitive. Steven Dickman

Although trade with the Soviet Union itself comprises less than one per cent of total exports, some West German industries expect to reap significant benefits from the agreement, especially in terms of sales to Hungary and other Soviet bloc countries. Many items remained on the CoCom list of restricted goods even though they were widely available on the world market.

One boon for West Germany lies in the decision to include specific descriptions of exceptions to the CoCom rules in the West German list. There is a simplified approval procedure for items included in the list of exceptions. The updated list is expected to be published some time this month.

But officials in West Germany have played down the economic significance of the meeting. The shortening of the list was seen primarily as a milestone in the political reconciliation between East and West. Peter Coles \& Steven Dickman 